\title{
THE ECOLOGY CHARAC TER OF BANDA ACEH CITY IN THE 17TH CENTURY
}

|Received December 12th 2016 | Accepted January 16th 2017| Available online June 15th 2017|

DOI http://dx.doi. org/10.18860/jia.v4i3.3872 |

Elysa Wulandari

Architecture and Urbanism,

Diponegoro University, Semarang, Indonesia

elysawulandari@yahoo.com

\section{Sugiono Soetomo}

Department of Urban and Regional Planning Diponegoro University, Semarang, Indonesia Soetomo_mpwk@yahoo.com

\section{Joesron Alie Syahbana}

Department of Urban and Regional Planning Diponegoro University, Semarang, Indonesia yoesrona@yahoo.com

\section{Asnawi Manaf}

Department of Urban and Regional Planning Diponegoro University, Semarang, Indonesia Asn2407@yahoo.com

\begin{abstract}
Bandar Aceh Darussalam as tamaddun city in the tip of Sumatera Island and capital city of 17 th century Islamic Aceh Sultanate, was a strategic coastal city. It had sloping beach and bays and was surrounded by mountains with rivers flowing through the city. Its wetlands-based urban development was reflected in the design of urban space structure and key elements of the city. It becomes inspiration for developing modern ecological city since 17th century Islamic cities in archipelago of the East is rarely studied. This research aimed to study the spatial concept of Bandar Aceh Darussalam. Data was collected by using the method of tracking physical information through ancient maps and field observation of the environment characteristic. It was found that the ecological character of the city seemed to be affected by the existence of integrated natural features, function and the role of the city that included Islamic concepts. The main elements of the city reflected the character of civilization in three aspects: the drainage system i.e. cut and fill, the scattered and wide empty space, and natural defense system. The concept of harmony between urban development and city's ecological character was shown in the design of urban landscape.
\end{abstract}

KFYWORDS:

Coastal city; tamaddun city; urban ecology

\section{INTRODUCTION}

The development of a city embodies the complexity of values prevailing at the time, therefore to understand the existence of the city can be achieved through ecological approach [1][2]. The approach of urban Ecology defines the city as an organic cell in ecological space [1], the city that is growing because there are internal forces that affect it, such powers can not be interfered by outside factors. The internal force that is known as the ecological character which will affect the pattern of urban development.

The city as a living space, can be understood with ekistics approach [3], that defines five elements forming the town, namely: man, nature, society, cell, network. If it is associated with ecological city, it will form the ecological character of the interaction of the elements forming the inner city.

The relation of the five elements in the formation of the ecological character of the city is that the existence of the universe can not be separated from the context in which the town is growing and developing, it will affect how the city was built to embody the interests of human life (social, cultural, economic and political community of the city). However nature has the potential and constraints that can be profitable and thus destroy the existence of a city [4] [5].

Ecological coastal town relates how the city is developed in the geographical environment of the coast which is affected by the dynamics in terrestrial and marine as well as the cultural life of the community with two cultures i.e land and sea [6][7][8][9]. This therefore makes the challenges of urban development complex.

Coastal cities, especially in the pre-colonial Southeast Asia, especially in the coastal Sumatran city has grown as a port town that was developed by a network of Muslim traders. Islam as a great religion has experienced success and dominated the civilization of the world [10]. Islam teaches harmony with nature, inspires ways to build the city as a cultural product. Therefore some of the principles of Islamic values will appear in the character of Islam [11], especially coastal cities in Indonesia Pre-Colonial [12][13].

Banda Aceh is located at the tip of Sumatra island which is very strategic for international shipping which connects the western and eastern regions of the World through the Indian Ocean and the Strait of Malacca [10]. The existence of the city of Banda Aceh is estimated to have existed prior to the gth century as the transit city of sea lane to the archipelago which was characterized with the Hindu kingdom that later became Islam in the XIII century [14].

In the sixteenth century it described that the 
city of Banda Aceh has grown as an Islam port city. In the seventeenth century town called Bandar Aceh Darussalam, evolved as the royal city of Islamic ideology, as well as cosmopolitan transit city for international sea lanes in Southeast Asia implying tamaddun character (tamaddun: a city appying Islamic character in all sectors of urban life). As one of the richest coastal cities in Asia, the ruler of the kingdom of Aceh lived luxuriously and stately with its environment utilizing all resources to strengthen its presence through various elements of urban design [10][15].

Bandar Aceh Darussalam looks to have a planned city form, in a vast flat area as its backgroundmountains with hills overlooking the sea, the rivers that cross the city. Various of main elements in layout and design are taken into account as the specific ecological character, so that the shape of the city (the city structure and land use) is connected with nature. Besides, certain values are reflected in the geometric forms in the urban spatial structure.

The design of the main elements of the city seemed to reflect the complexity of an idea to achieve certain goals that are meaningful to the life of the city. The design integrated space between human activities and natural dynamics. Islamic values have been implied in structuring the concept of the city, considering the time it is the triumph of Islam in Aceh, so the tamaddun city is as seen through its spatial design.

This research aimed to know how to optimizing the concept of region design using Islamic approach into wetland geographical condition, so that city's ecological system is in balance and harmonious with human's needs. Research about Islamic city, especially in Southeast Asia in pre-modern age, is so rare, but its design principles seem to have universal value. Therefore, this research will be useful for city design development in wetlands.

\section{METHODS}

The study begins with understanding the spatial characteristics of the city of Banda Aceh XVII century (Bandar Aceh Darussalam) through maps, sketches of the city and old photographs that are connected with stories of social history, culture, politics, economy during the era. Data is associated with characteristics of two aspects: 1) the physical elements of the main town: and 2) environmental resources town.

Study of spatial old town to determine the physical limits of the city will be examined. Then identification of the existence of some major elements of the city will be carried out, further the location will be clarified with the current state to justify its existence geographically.

Data were analyzed by crossing and checking each other between the physical aspects of the main elements of the city and its natural environment using the method of morpho - physical tipologi. The foot print of the main elements of the old city is still well identified, although not all of the physical form are intact. Additionally the natural environment data allegedly linked to the presence of the main elements of the city are also studied to explore the possibility and the development of concepts of design elements of the city that comes from the potential of the natural environment.

Discussion of the data is done by the method of logical argumentation [16] by explaining the concept of the design elements that support the existence of the town city. Besides, it also carried out a comparative study of the elements of the city through the study of literature, to explain the truth of the design elements of the city and the possibility of a universal value system as a background design concept

\section{STUDY AREA}

\section{NATURAL ENVIRONMENTOF BANDA ACEH ON THE TIP OF SUMATRA ISLAND}

Banda Aceh is located in coastal wetland environment, potentially developed by utilizing the diversity of existing environmental resources. Coastal environment and biodiversity in wetlands created either in the form of land, flora and fauna [17] allows the processing of urban elements into a variety of shapes and characters according to the needs of human activity [18]. In contrast, coastal environment has multi-complex susceptibility of the dynamics of the ocean waters and the archipelago that can change the type of coastal plains [8]. This is apparent when the 2004 tsunami in Banda Aceh sea waves ran into the mainland to $3-4 \mathrm{Km}$ which caused a third mainland broken city, changing the coastline [19].

Human activities in urban wetland that is reflected in the character of the utilization of urban spatial elements will affect the processes of system of hydrology, geomorphology and local ecology [20], therefore the construction in wetlands requires maintenance of the potential environmental resources [21]. The higher a civilization in the coastal city of wetlands, the better the ability to build the city with better aspects of conception and technological aspects. Otherwise your presence in the seaside town will be easily destroyed and civilization will be lost.

Banda Aceh is located on the world slab between two fault-shaped on the moutainious hills rowed in the Western and Eastern regions. Geographical character in the form of plots of land sloping beach wet is the result of geomorphological fracture process (faulting Ridges) and subsidence (graben) hills.

Fault slab dynamic world often cause earthquakes that have an impact on the decrease in some parts of the urban land that affect a building on it [22][23]. Mainland of Banda Aceh with various forms of land from the swampy land to solid ground toward the hills, flowing many grooves are tipped in the hills around the city and form some streams (fig.1). Mouth of the river is the entrance to the mainland through a sea voyage [10]. 


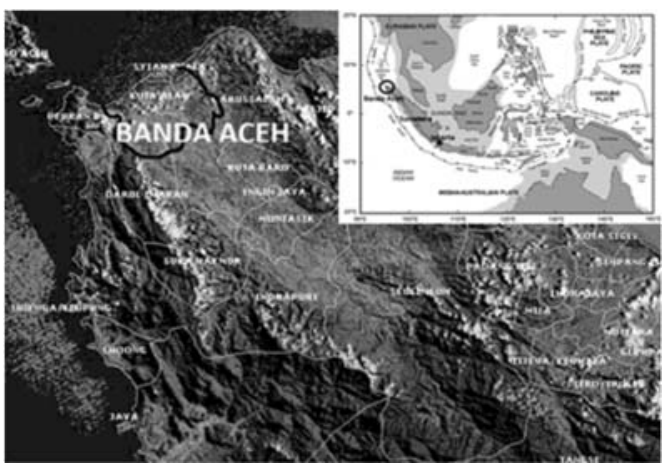

Fig. 1: Banda Aceh in Sumatera, Indonesia

In addition, the character of Banda Aceh regional climate, high rainfall that caused a flood-prone area of the city on the annual rains and storms that damage the building. Flood events as a form of flood from the hills greatly affect the condition of city land. According Craghan [24] floods can change the shape of the land with the supply of sediment during floods.

Since the seventeenth century, the character of the natural environment of Banda Aceh has inspired patterns artificial city environment design by adjusting the patterns of urban land use. Airoldi [25] argued that the processes of the natural environment will affect the sustainability of the distribution, diversity and maintenance diversity of human activities which are formed in the town hall. This means that the design of the city must be able to respond to the dynamics of the natural environment, it will be important for the sustainability of the existence of a town.

\section{HISTORY OF BANDA ACEH: FROM TRANST CITY TO COSMOPOUTAN-DEENSE CITY}

BANDA ACEH BEFORE THE XVII CENTURY: THE SMAL TOWN OF THE ISLAMIC EMPIRE AND THE TRANSTTCITY

Starting from the first Islamic empire Aceh XIII century, which removed the center of the kingdom (In the Palace) in Lamuri seaside (Kp. Java today) South to the mainland as far as $6 \mathrm{~km}$ in the western outskirts of Krueng Aceh river. The Options seem to be influenced by Hindu cosmology that put streams into the imaginary link between the profane area (sea) in the North, Palace area (middle) and Sacred area (hills) in the South [14]. Position In the palace is still exist.

In the geographical character of the palace later became the location of the center of the city of Banda Aceh which is relatively free from flooding from Krueng Aceh river since dueto its position at the back bend of the river flow. If associated with a character stream, generally, the back bend of the river flow are characterized by harsh land and relatively high, so that the flow turns.

Besides, the location in the Palace is in the land covered view of the sea, by the coastal plain of sand and marsh area. It is very positive for the existence of the city from various reviews: safety climate effects (storm, waves), security and defense toward the disturbance of migrants from the sea.
In the sixteenth century as a royal capital of Banda Aceh Darul Kamal called Dar-ud Dunya, is a transit town, causing the city of Banda Aceh experienced expansion towards the west coast estuaries role Krueng Ulee-Lheue river as a pathway to the city. Downtown city flourished in the area between the Krueng Doy river and the Krueng Aceh river.There are three elements that make up the Main functions of city structures, namely: Market, Mosque and Sulthan Palace. See the picture below (fig.2):

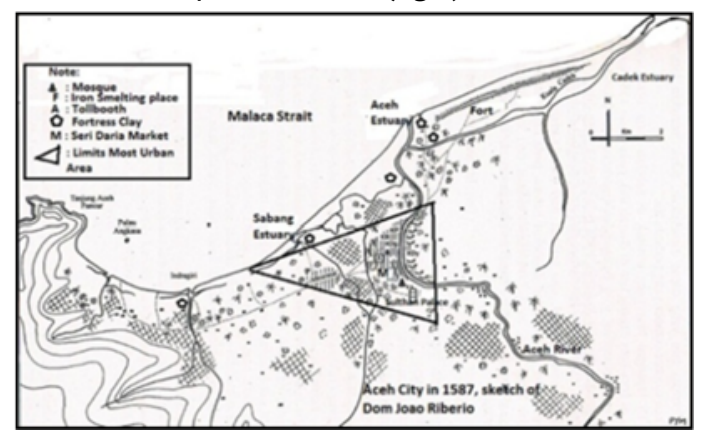

Fig. 2.The Map of Banda Aceh sketch in 1584

Laying pattern of the city's main function extending from north to south in a row, namely: Regional Port, Trade Village, Mosque, and the Sulthan Palace. Mosques and palaces connect to the city functions. The flow of the river serves as the primary means of transportation to the area outside the city.

From the Landscape character of the city, we can see the castle (fortress clay) located at the estuary of the river and on the eastern land of the city. If it is associated with political conditions, it seems that in the sixteenthcentury the invaders had started to colonize the city, although Banda Aceh is physically a small town, but it is very strategic for the entrance to the Southeast Asian region through the Strait of Malacca.

In the sixteenth century after the unification of the two kingdoms and crowns Darul Kamal Alam the royal capital of Aceh Darussalam was renamed as Bandar Aceh Darussalam. Kingdom of Aceh started to cooperate with Turkey by bringing soldiers and artisans in the two vessels that later resided and built a village in Bitay (Lamteumen now) [26]. Turkey's role begins with the construction of the royal palace (In the Palace), a large fort at the mouth of the river (as a guard post) and Gunongan (place of spiritual activities and playground). This marks that the city of Banda Aceh was an instrument to the political world as well as the city asserted forward to its time.

If Aceh is associated with the Turkey triumph of the XV century in term of city defense aspects [27], and the beginning of the sixteenth century where European coutries expanded into Southeast Asia [10], the possibility of constructing three main elements of the city as the defense strategy part of town. Sloping character of the urban landscape and marshy made it difficult to monitor and shelter from enemy interference, hence the need for artificial landscape elements are high and difficult to reach in the city area. 


\section{BANDA ACEH XVII CENTURY: COSMOPOUTAN AND TAMADDUN CTY}

In the 17th century, Bandar Aceh Darussalam became a cosmopolitan country due to political and economic developments in the Middle East and Europe [26]. Diverse nation and the character of economic life, social and cultural cities, such as: the Arab-Turkish, European, Chinese, Indian, Malay live in harmony [28]. Banda Aceh city experienced significant expansion in the sixteenth century appeal.

Kingdom of Aceh has an Islamic ideology which was affiliated to the Turkish empire. It affected all aspects of urban life, including in urban planning [15], so that Banda Aceh is transformed to a city widening in all its directions with the more complex city design.

Bandar Aceh Darussalam as international maritime port city, has a port as well as the city center (economic activity) in the estuary and along the city's main Krueng Aceh river flow (fig.3). The Traces of the old town supporting the activities of the city still exists up to today with the naming of the village appropriate with community activities such as Pande village (village of Iron workers).

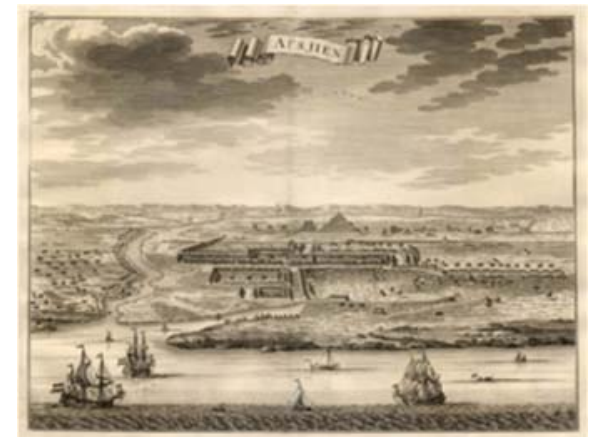

Fig. 3. Painting the town of Banda Aceh in 1724, revealing the character of maritime town in coastal wetlands

Bandar Aceh Darussalam as Tamaddun and cosmopolitan city, meaning that an advanced civilized city, a center of civilization to develop the teachings of Islam, as well as implementing Islamic values in everyday life are included in the arrangement of artificial environment. Consequence of the role of cosmopolitan cities is such as providing the complex function. Figure 4 shows the activity in the city of Banda Aceh in the age of Aceh kingdom which was drawn in 1873 after losing the Dutch colonial war.

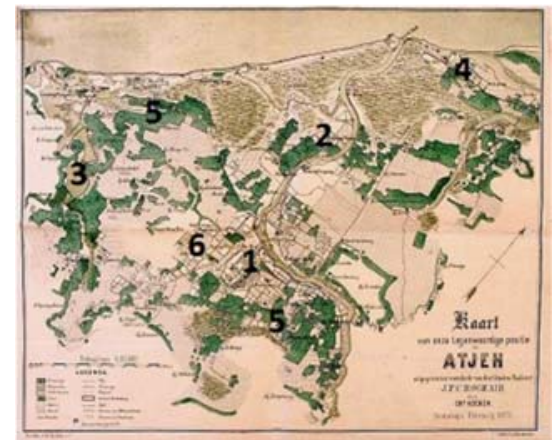

Fig. 4. Traces of Banda Aceh the kingdom of Aceh, and location of the city mayor elements, drawn in 1875
The Spatial planning of Banda Aceh at the end of the seventeenth century Aceh empire reveals some major elements of the city, namely: 1) City center: open field connecting the Palace, Mosque and market adjacent to the city's main river of 'Krueng Aceh'; 2) port and airport support facilities along the Krueng Aceh river; 3) military area along the Krueng Neng river; 4)Regions dayah education Syiah Kuala; 5) Settlement Region integrated with agricultural region, composed of two types, namely settlements in swamp land at the northern part of the city and settlements in the south of the city.; 6) Park area: Bustanussalatin; 7) Region water sources (Aquatic) in mountain; 8)The road network.

\section{THE ECOLOGY OF THE BANDA ACEH IN 17TH CENTURY}

\section{CITY STRUCTURE: PATIERNED RADIAL ROAD, FORIIRED AND DITCHED VIUAGE}

The structure of the city is mostly shaped in the road network pattern and land use settlement; the city center is located near Krueng Aceh river flow. The city is integrated with the utilization system of Krueng Aceh river flow as a liaison to the northern area of the city as a pathway towards the sea and to the South as a connector to remoted area. Downtown as the center of the city with driver development patterns across the road leading to the radial winds, although not look symmetrical. Road as liaison functions other major cities in particular settlements scattered in a wide area and loose (fig.5). The morphology of the city region is affected by three factors.

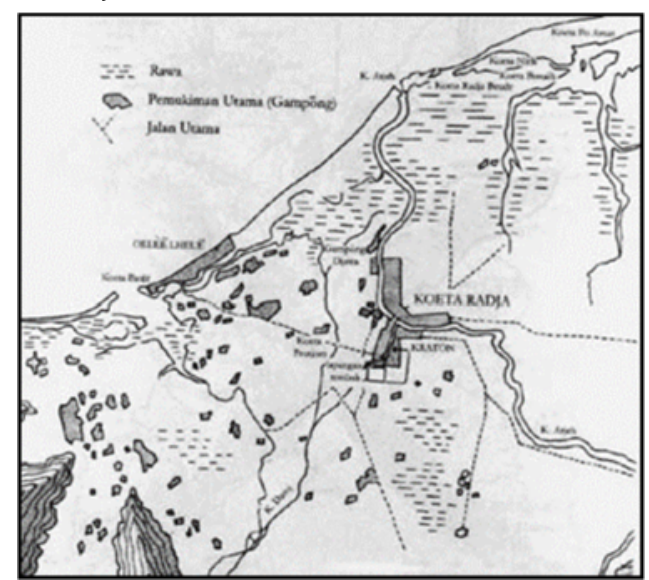

Fig. 5. Structure of Banda Aceh at the end of Aceh empire in the19th century

\section{NATURALENVIRONMENT, CONSISTING OF: MARSHY LAND AND STREAMS CHARACTER}

Swampy land character affecting the way to build the future path to the location of settlements are scattered in the form of straight lines form the bund (embankment). By spatially build bund road in wetlands, it will be efficient if a straight line, because there is no reason to veer-steered road. Therefore, it is not difficult to build roads shaft with cut and fill process that will create the road embankment and 
ditch. In the development of the city, the settlement seemed to grow around the road embankment, which tended to be in linear pattern. While on the back side of the village the land was used as paddy fields to buffer the settlements.

The character of the river flow, the right and left river (i.e Krueng Neng and Krueng Cadek respectively) looked physically to limit the urban development area, because it will complicate the mobility in urban space. Whilst Krueng Aceh river which crosses the city center looked to be the central of the city development surrounded with the growing activities.

\section{MARTIME CITY IS CONCERNED WTH THE ECONOMIC AND POUTICAL CHARACTER}

Character of the maritime economy, associated with the port area and maritime city makes a dynamic city with a variety of supporting economic activity. Experience in many countries, maritime trade activities will lead to the diversity of activities surrounding both support and utilize the existing economic activities $[29,21]$. Economic activities in the city looked to be developed around Krueng Aceh river which causes the northern area of the town growing solid.

Politics maritime character, associated with aspects of defense and security to keep the area of the city from attack by the sea. The development of the city seemed to be directed to the north of the city along the coast by building defense function both physically (castle) and the center of military activity in the right and left parts of the city area Krueng Neng estuary of the river flow and Krueng Cadek estuary.

The second position is very strategic area to keep the city from the East and West of the sea. The area between the city center and the region grew as residential and agricultural land.

\section{CULTURALFAC TORS SOCIETY, REATED TO THE CHARAC TERS ON THE WETLAND SETILMENT}

The pattern of urban settlements looks like 'islands' in castles form surounded with ditch spreading over vast swamps. On the outskirts of the village there are gardens surrounded with ditch around the village which is planted with palm trees.

There seems to be something unique in the form pattern. It is estimated that building on a swamp area was donr by cut and fill system. Dugouts are used to hoard (Fill) an area used as residential location, whilst land excavation (cut) is designated as agricultural land belonging to the community of the settlement.

When it is raining which can cause flooding the city, then the rettlement is flood-free; and the rice fields becomes as a reservoir for water runoff. Character of the urban settlements appeared to be a system of land-use planning and environmental management considering ecological character. Traditional village as above is still visible around the city of Banda Aceh.

\section{PRIMARY ELEMENIS OF URBAN DESIGN}

\section{CITY CENIER AREA: IN A FORTIFED PALACE SURROUNDED WTH DITH}

The character of city center in the early seventeenth century puts four main elements (In the Palace, open fields and a river pier, mosques and centers of trade) which were designed along the Krueng Aceh river without fort. The fort is only around important buildings such as In the Palace and Mosque (fig.6).

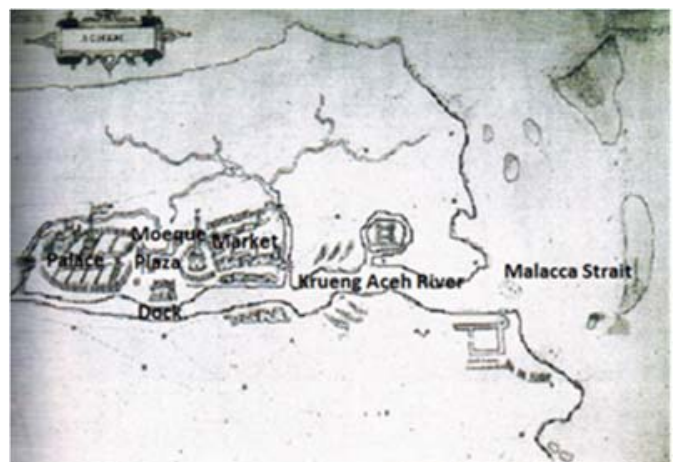

Fig.6. Sketch of the town's main function settings at the edge of Krueng Aceh river in 1600

Mosque is located in an west of the open field west (Java: alun-alun) and watersheds Krueng Aceh which is in accordance with the position of the sacred mosque. Open field with dock landing of Krueng Aceh river as the court entered the area from the river would be very profane, it is like a plaza and Stoic Greek times (fig.6) [29]. Banda Aceh city center is a blend of Hindu-Muslim cosmology wheelbase in the open field [14]. While trading activity oriented to the north of the city back to the mosque area. Thus the city appears to used as a political and religious center. Sketch of the early seventeenth century city looks in the figure 6 .

By the end of the seventeenth century, the design of the town center looks grown by adjusting the political and economic conditions of the city. In the central city and the palace as a symbol of power seemed to be the center of the city orientation. There are two areas of concern in the draft in the palace, namely: 1) In the region Beyond the Palace Walls: Solidly fortified in swampland Outsied of the palace is developed as a fortified area with sturdy construction, as described by Lombard [15] that: In the palace has fortified walls formed along $2 \mathrm{Km}$ from the cut and fill. The digged trench outside the walls reaches a depth of 10 meters, the quarry into the castle wall with bamboo trees planted on it with a density of trees that can not be viely penetrated. From the aspect of internal defense, castle design with the outer side of the ditch, will make it difficult for people to enter, climb and attack in the Palace. In addition, the composition of the bamboo tree, will form a transparent wall useful in observing everything from the top of the castle without being known from outside the fort through the cracks of the bamboo tree. This is presumably derived from the Chinese concept of landscape, 
considering the role of China is also high in the kingdom of Aceh life XVII century. Technically bamboo tree is excellent for the wetlands with embankment, since its roots as constructive support for the ground protecting them from the landslides. While trees with rare leaf from top to bottom is very good for the environment with extreme air between hot / dry and rain ( storms, as a porous wall; 2) Landscape In Palace: streams and gardens "paradise". There are several buildings and open space with artificial river flows from south to north in the center of the palace area. The area is functionally designed to support the life of the king, the king's family and servants. There are gardens with wet vegetations in the palace area. The existence of the element of water in the park is very important. As Lombard [15] said that the park will be significantly high as heaven with tranquility which is used by the kings for doing the evening worship activities. Ritual activity such as meditation is very important for supporting his function as the king. Water flow in the Palace is common for being applied in the Islamic cities in the archipelago [12]. Garden and Water are used as the embodiment of Islamic values, to the function of worship, spiritual and pleasure/comfort.

\section{MILTARY AREA IN NATURALENVIRONMENT: SPRINGS STREAMS AND PONDS ATBEACH}

On the 17th century the city of Bandar Aceh Darussalam was very interested to develop a maritime military education, thus giving birth to many admirals war in the future. The Location of the maritime military training was predicted to be developed in the occupation of the Turks in the area along the Krueng Neng river, because this location was early resided by Turkish nation. Traces of settlements of Turkish descent can still be traced which now serves as a military area (fig.7).

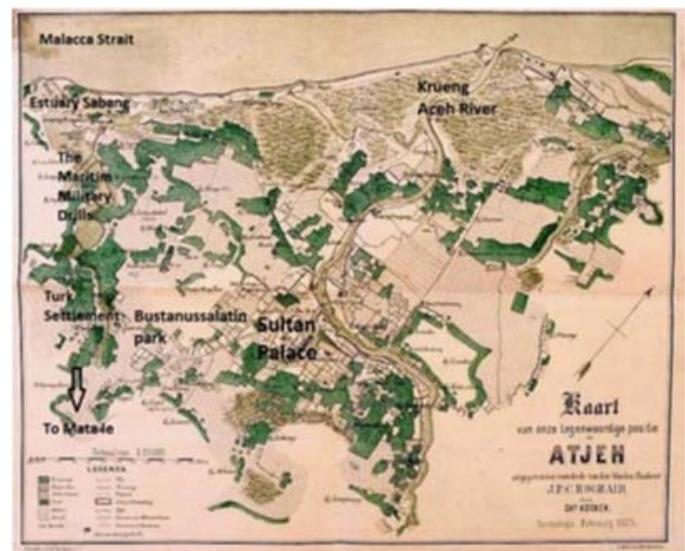

Fig. 7. Location military area at Krueng Neng river

The selected area for military seems logical in ecology view, due to the geographical character of a connection hills, rivers and coastal areas in the region. Hills were used as a natural fortress. Foothills area was ideal for the habitat of elephants and also an ideal place to practice. The flow of the river as a source of life and maritime military training, and the beach as the area to be protected.

Development of the area along the Krueng Neng river as a military area of Bandar Aceh Darussalam, seemed to adopt the concept of the Roman city that was also developed in Turkey XV century [27]. Krueng Neng river was as water supply systems for military region as well as a means of military training and aquatic dammed upstream in the foothills of Mata le in the South Region. Krueng Neng stream near the beach looked like an artificial pond the form of regular geometries. It was probably an military exercise, due to natural estuaries sloping Krueng Neng river tends to be sedimentated and evolved into a swamp and mangrove trees growing with organic shapes. Curently the pool is still exist and used as flood control pool in the western part of the city.

From the political aspect of the defense, the choice of location is very strategic for military region in maintaining the security of the city from the West side.

\section{BUSTANUSSALATIN PARKS AS CITY FOREST, HERBAL MEDICINE AND RECREATION PARK}

In 1613 the Krueng Daroy river canal was built flowing in to in the Palace. Very beautiful garden was built throughout the artificial canal. Many sources tell where the garden of Bustanussalatin, Position enormous garden lies to the west in the Palace of the king who received artificial river flow (Krueng Doy current) of the springs in the foothills west of the city. See image reconstruction Bustanussalatin park by Arief [14] and the current conditions in the middle of the pond Pintho Khop built XVII century (fig.8). There are thousands of species of plants, of vines, shrubs, and perennial logs with a very complex arrangement and beautiful [26].

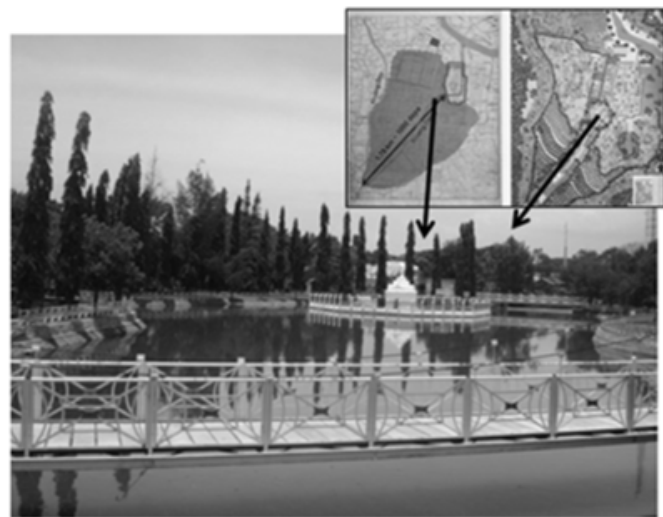

Fig.8. Reconstruction of the park Bustanussalatin and the current conditions Pintho Khop

Based on the picture of the Bustanussalatin park and Krueng Daroy river, it seems that it served as the complex urban forest park that serves the following functions, namely: 1) Hydrology Technical functions. Krueng Daroy and Krueng Doy rivers seemed to be technically developed as a flood channel, so when it was raining, flood water was diverted from Krueng Neng river, so there was no flooding in the river mouth area of Krueng Neng which was developed 
into residential areas and productive rice fields. Krueng Doy was flowed toward the rice fields in the north of the city, it appears to function as a technical irrigation system. Currently the area around the Krueng Doy river was developed as a residential area. Whilst Krueng Daroy river was distributed in piped into the palace. Along the river watersheds Krueng Daroy was developed in steps, parks and ponds on either side of the river, during the rainy season (September-March) that can cause flooding in the city, the river can put a halt to water which can then used to provide water during the dry season period. Parks will be fertile throughout the year due to sufficient water is available from the artificial ponds. Thus the problem of flooding in the city region has been solved by the presence of Krueng Neng river and at the same city will be green; 2) Climatology function. Position park west of the palace is very helpful in reducing the very strong west wind in the transition period (May to July), and the dry season (April to August). Enormous garden will reduce wind around the city, the character of a broad sloping land with hills formed a strong rotating wind; 3 ) Health Function. Role of cosmopolitan city requires the availability of good health facilities. In the tradition of the 15th century Islamic city, the treatment for illness which is based on the knowledge that comes from Qur'an implies God provide the cure for every illness. As a city with a large population and a high diversity, the provision of environmental medicine must always be maintained, so that the forest herb garden as herbal medicine becomes important. Meanwhile in the West part of Bustanussalatin Park, adjacent to the military region, is said to have a very complete hospital, so that the park supports the existence of the hospital; 4) Recreation and Aesthetics Function. Structuring the park and river flows in the form of geometric describe the functions of recreation for beauty. Structuring concept seems to refer to the concept of Heaven is described in the Qur'an.

\section{MATA IE REGION: SOURCES OF CLEAN WATER, RECREATION PARK AND MIUTARY EEPHANTTROOPS REGION}

Mata le region as a major supporter of the region where the city of Bandar Aceh Darussalam, which is about $8 \mathrm{~km}$ on the west of the city, which is located in the foothills of the limestone mountain that has many springs and flows to the west coast of the city. Mata le region seemed to be designed as an area of urban water supply source, as well as recreational areas for the king, amaintenance and training of troops of elephants. Associated with the concept of the kingdom of Aceh military development with the help of the Turkish empire, the concept of water source region resembles to the concept of aquatic Roman period [5] and some of the ancient Islamic city in the Middle East region.

Water supply system was built in the form pools and dams, thus availability of water can be controlled. The pools are built also serves as a recreational area and a king banquet reception for welcoming foreign guests. The concept of dams in the development of Islamic settlements also appear in some places where Islam had ever been ruling in the town such as Plered in Yogyakarta [12].

Mata le region also estimated as a military training for elephat troops area which is up to thousands elephants, considering the area is suitable for elephants habitat and connected with the Turkish military area. Functional military, will facilitate the integration of the functions of the command, due to the lack of physical communication system.

\section{DISC USSION}

Bandar Aceh Darussalam as shown in the picture as a tamaddun city, town built using the principles of modern science at that time and until now scientifically proven to contain modern truth.This can be seen from three aspects: 1) Cut and Fill Drainage System in the City. It seems that Since the seventeenth century flooding has been a problem for the city of Banda Aceh through overflowing water from Krueng Neng and Krueng Aceh river. The design of the city seemed to take into account the potential and constraints of both these rivers, so the city was designed by the system to control the city hydrology and reduce the impact of flooding of the city. The development of Krueng Daroy dan Krueng Doy river appear as flood control and drainage system of the city that was built with the cut and fill system to form a trench at the same time a high mound on the outskirts of the river, forming two elements, namely castle moat and walls. Thus the river seems to be the limit of the development of the city center. Typology of urban structure surrounded with embankment and ditch patterns is as a consequence of building on wetlands to organize regional drainage system. It thus appears to be a general pattern of the cities that was developed in the seventeenth century in the archipelago [13], also found in Southeast Asia continent, such as in Cambodia, Thailand [30]. The concept of cut and fill is something logical in developing habitable place on wetlands throughout the rainy season, soil excavation will be a good source of material for the construction of the landfill as well as for the manufacture of building land. Bandar Aceh Darussalam as tamaddun city can be seen from people's ability to read the character of nature that can change and set the environment for the sake of sustainability of physical life space while creating functional spaces of the city; 2) Non-built space, Loose and Spread. Development in wetlands that are often flooded, also need to consider their water catchment areas which are scattered in an area [31], therefore, non-built space in urban areas is very important. The structure of the city of Banda Aceh were "loose" in the form of rice cultivation which is something true, Since it creates spaces for water absorption. Rice cultivation can serve to support the spread of urban life source in spaces adjacent to the city of settlement functions. In the development of the city, the morphology plan provides the green open spaces from a non-built 
region into the built one which function as rice fields, gardens and ponds around the river and as the functional area of the city. Thus the ecological aspects of the city took place in the balance among the interests of human, natural and urban. This condition shows that the city of Banda Aceh is a tamaddun city, which is able to establish the city as a civilized, prosperous and ecological; 3) Natural Defense: river, castle and garden soil. When the city's existence is threatened by foreign nations desire control of Aceh who came from the direction of the sea, the city is very vulnerable because it is physically not well protected. As a coastal city that does not have a nearby hil landscape elements, making the city of Bandar Aceh Darussalam physically open to the sea, so that aspect of the defense and protection of the city needs to create an artificial element. Forts around the orchard beach seemed as an artificial element in the framework of defense of the city from the sea. If the observed natural resources available, the castle looks to be built from the excavation around the seaside. Land in the form of plots dug ponds or rice regular pattern, it appears that the land in print also for functional interests. Thus the treatment of the land to the functional city has also changed the shape of the land, so it can be said to occur micro geomorphological processes in the city due to human activity. It looks that the development surrounding residential such as land was used as a source of local community life. The character of the community still exists up to today, including land ownership pond. The role of coastal forts associated with the role of the river which was also developed as a natural fortress designed a functional part of the city, so that the end of the seventeenth century, the area of Bandar Aceh Darussalam looks at fortify by natural features, although in certain places remain with the natural elements: river, garden, hills. Character of the city looks different from the character of ancient cities that was flourished in the Middle East and Europe that formed a massive fortified city wall [4][5]. Picture as tamaddun city appears that the political aspects, economics and ecology can be combined in the element structure of urban space both natural and artificial.

\section{CONCLUSION}

Spatial development of Banda Aceh in the 17th century appeared to have control of the hydrology, geomorphology and ecology process of the city through a cut and fill system in the construction of the main elements of the city and biophysical procurement as supporting elements (gardens, parks and animals). Regional city located in wetlands near the coast is very risky to floods and tides, therefore artificially modified forms of land (artificial geomorphological processes) will influence and control the process of modifying the hydrology and ecology of the region as well as the construction of parks and ponds; dike roads, settlements and rivers; and patterns of urban land use integration between developed and undeveloped land and the not-built one (agricultural land).

The concept of building on a swamp, looks good and has evolved into a tradition in building the city, therefore in the testimony the foreigners, Beaulieu in 1620, mention that the character of the city of Banda Aceh is that the people of Aceh is expert in making trenches [15].

Tamaddun city is characterized in the ability to process natural elements by applying the idea / Islamic values for complex urban purpose, namely: economic, socio-cultural-religious, political-defense. The name of the city as Darussalam which means peace, also envisaged the integration of functions city into the open green spaces. It looks that there was an effort to make the city as a heaven on earth, heaven is described as a character which has a flow of water and greenery plants such as orchard and garden for getting a joy as described in the Qur'an.

\section{ACKNOWFDGEMENTS}

The authors would like to acknowledge the support of The Directorate General for Higher Education, Ministry of Education and Culture, Indonesia.

\section{REFERNCES}

[1] D. . Williams, Sustainable Design: Ecology, Architecture and Planning. USA: John Wiley \& Sons, 2007.

[2] R. Forman, Urban Regions: Ecology and Planning Beyond The City. New York: Cambridge University Press, 2008.

[3] C. A. Doxiadis, Ekistics An Introduction to The Science of Human Settlements. Oxford: Oxford University press, 1968.

[4] S. Eisner and A. Gallion, The Urban Pattern. 6th ed. New York: Van Nostrand Reinhold, 1986.

[5] S. Kostof, The City Shaped: Urban Pattern and Meanings Through History. London: A Bulfinch Press Book, 1991.

[6] J. Colding, "Ecological Land-Use Complementation' for Building Resilience in Urban Ecosystem," Landsc. Urban Plan., vol. 81, pp. 46-55, 2007.

[7] A. R. Farhan and S. Lim, "Resilience Assessment in Coastline Changes and Urban Settlements: A case study in Seribu Islands, Indonesia," Ocean Coast. Manag., vol. 54, pp. 391-400, 2011.

[8] A. Newton and J. Icely, "Land Ocean Interactions in the Coastal Zone, LOICZ: Lessons from Banda Aceh, Atlantis, and Canute," Estuar. Coast. Shelf 
Sci., vol. 77, pp. 181-184, 2008.

[9] F. Numberi, Perubahan Iklim: Implementasi Terhadap Kehidupan di Laut, Pesisir dan Pulaupulau Kecil. Jakarta: Fortuna, 2009.

[10] A. Reid, Asia Tenggara Dalam Kurun Niaga 14501680, Jilid 2: Jaringan Perdagangan Global. Jakarta: Yayasan Pustaka Obor Indonesia, 2011.

[11] O. A. Hoesin, Kultur Islam : Sejarah Perkembangan Kebudayaan Islam dan Pengaruhnya dalam Dunia Internasional. Jakarta: Bina, 1981.

[12] I. Adrisijanti, Arkeologi Perkotaan Mataram Islam. Yogyakarta: Penerbit Jendela, 2000.

[13] B. Wiryomartono, Seni Bangunan dan Seni Binakota di Indonesia. Jakarta: PT Gramedia Pustaka Utama, 1985.

[14] K. A. Arif, D. Muhammad, and E. Endarmoko, Ragam Citra Kota Banda Aceh: Interpretas Sejarah, Memori Kolektif Dan Arketipe Arsitekturnya. Bandung; Banda Aceh: Pustaka Bustanussalatin; BRR NAD-NIAS, 2008.

[15] D. Lombard, Kerajaan Aceh Zaman Sultas Iskandar Muda (1607-1636)., Terjemahan. Jakarta: KPG Forum Jakarta-Paris; Ecole Francaise d'Extreme-Orient, 2006.

[16] L. Groat and D. Wang, Architectural Research Methods. New Jersey: John Wiley \& Sons, 2013.

[17] T. Kuleli, A. Guneroglu, F. Karsli, and M. Dihkan, "Automatic Detection Of Shoreline On Coastal Ramsar Wetlands Of Turkey," Ocean Eng., vol. 38, no. 10, pp. 1141-1149, 2011.

[18] M. Alberti, D. Booth, K. Hill, B. Coburna, C. Avoliob, and S. Coed, "The Impact of Urban Patterns on Aquatic ecosystems: An empirical analysis in Puget lowland sub-basins," Landsc. Urban Plan., vol. 80, pp. 345-361, 2006.

[19] M. Umitsu, C. Tanavud, and B. Patanakanog, "Effects of Landforms on Tsunami Flow in the Plains of Banda Aceh, Indonesia, and Nam Khem,
Thailand," Mar. Geol., vol. 242, no. 1-3, pp. 141153, 2007.

[20] J. Ehrenfeld, "Evaluating Wetlands Within An Urban Context," Ecol. Eng., vol. 15, pp. 253-265, 2000.

[21] R. May, "Connectivity in Urban Rivers: Conflict and Convergence Between Ecology and Design," Technol. Soc., vol. 28, no. 4, pp. 477-488, 2006.

[22] J. R. Curray, "Tectonics and History of the Andaman Sea Region," J. Asian Earth Sci., vol. 25, no. 1, pp. 187-232, 2005.

[23] E. Meilianda, "Past, Present and Future Morphological development of A TsunamiAffected Coast, A case Study of Banda Aceh.," University of Twente, Netherlands, 2009.

[24] M. Craghan, "Sediment Delivery and Accumulation in a Developed Area During Coastal Floods," Geomorphology, vol. 69, no. 1-4, pp. 5775, 2005.

[25] L. Airoldi, A. Marco, M. W. Beck, S. J. Hawkins, P. R. Jonsson, and D. Martin, "An Ecological Perspective on the Deployment and Design of Low-crested and Other Hard Coastal Defence Structures," Coast. Eng., vol. 52, no. 10-11, pp. 1073-1087, 2005.

[26] A. Reid, Menuju Sejarah Sumatera: Antara Indonesia dan Dunia. Jakarta: Yayasan Pustaka Obor Indonesia; KITLV, 2012.

[27] F. . Siauw, Muhammad Al-Fatih 1453. Jakarta: Alfatih Press, 2013.

[28] A. Hadi, Aceh: Sejarah, Budaya dan Tradisi. Jakarta: Yayasan Pustaka Obor Indonesia, 2010.

[29] A. B. Gallion and S. Eisner, The Urban Pattern. USA: Van Nostrand Reinhold, 1986.

[30] M. Freeman and C. Jacques, Ancient Angkor (Books Guide). Thailand: Amarin, 2012.

[31] D. Noor, Geologi Lingkungan. Yogyakarta: Graha Ilmu, 2006. 